\title{
Pseudohypoaldosteronism due to Sweat Gland Dysfunction
}

\author{
SUDHIR K. ANAND, ${ }^{(50)}$ LINDA FROBERG, JAMES D. NORTHWAY, MYRON WEINBERGER, AND \\ JAMES C. WRIGHT \\ Department of Pediatrics and Internal Medicine, Indiana University School of Medicine, Indianapolis, Indiana, USA
}

\begin{abstract}
Extract
Pseudohypoaldosteronism is an uncommon disorder characterized by urinary sodium wasting and is attributed to a defect in distal renal tubular sodium handling with failure to respond to endogenous aldosterone. Sweat electrolyte values in other reported patients, when measured, have been normal. A 3.5-year-old gigl developed repeated episodes of dehydration, hyponatremia, and hyperkalemia during the first $\mathbf{1 9}$ months of life. Serum sodium was as low as $113 \mathrm{mEq} /$ liter and potassium as high as $11.1 \mathrm{mEq} /$ liter. Her plasma and urinary aldosterone levels were persistently elevated (Figs. 1-4). Unlike patients with classic pseudohypoaldosteronism she demonstrated no urinary sodium wasting (Figs. 2 and 3). During episodes of hyponatremia and reduced sodium intake her urinary sodium was less than $5 \mathrm{mEq} /$ liter. In addition, her sweat sodium concentration was consistently above $125 \mathrm{mEq} /$ liter and salivary sodium concentration above $58 \mathrm{mEq} /$ liter. Her chest $\mathrm{x}$-ray, 72-hr fecal fat excretion, serum and urinary pancreatic amylase (amy-2) were normal, providing no evidence for cystic fibrosis. It is proposed that this patient represents a new variant of pseudohypoaldosteronism with excessive loss of sodium from the sweat and salivary glands instead of the kidneys.
\end{abstract}

\section{Spectulation}

Aldosterone is known to control sodium and potassium excretion by kidneys, sweat glands, and salivary glands. In patients with classic pseudohypoaldosteronism there is a defect in renal tubular response to aldosterone action. Studies in the present patient suggest that there may be variants of this syndrome in which the end organ defect is in the sweat and salivary glands instead of the renal tubule. In addition, it is possible that new variants will be found in which end organ defect is in still other organs concerned with electrolyte transport.

Pseudohypoaldosteronism is an uncommon renal tubular disorder characterized by urinary sodium wasting and is manifested by repeated episodes of dehydration, hyponatremia, and hyperkalemia $(1,5,7,11,17,22,32-35,37,38,44)$. The abnormality in this condition is attributed to an end organ defect in the distal renal tubule with failure of response to endogenous aldosterone. Aldosterone secretion and/or urinary excretion rates are usually elevated $(11,22,33,34)$, but during very high sodium intake in some patients the rates fall to the normal range $(11,22)$. Other adrenocortical functions are normal. Sweat sodium and/or chloride determinations, when measured, have been reported to be normal $(5,11,34,35)$.

We have observed a 3.5-year-old Caucasian girl with normal growth and development who, during the first 19 months of her life, developed repeated episodes of hyponatremia, hyperkalemia, and dehydration with serum sodium as low as $113 \mathrm{mEq} /$ liter and serum potassium as high as $11.1 \mathrm{mEq} /$ liter. Her plasma aldosterone level and urinary aldosterone excretion rates were persistently elevated whereas other adrenocortical functions were normal. Unlike other patients with classic pseudohypoaldosteronism, she had no urinary sodium wasting when studied during dietary sodium restriction and her sweat and salivary sodium concentrations were persistently elevated. She did not appear to have cystic fibrosis. This report describes studies related to changes in sodium intake and their effects on sodium balance and aldosterone production. The results suggest that this child represents a new variant of pseudohypoaldosteronism in which the end organ defect is in the sodium metabolism of sweat and salivary glands instead of the renal tubule.

\section{CASE REPORT}

$R C$ is a 43-month-old Caucasian girl who was first referred to the Riley Children's Hospital (Indiana University Medical Center) at 28 days of age for failure to thrive, difficulty in breathing, and shock. She was the product of a normal pregnancy and delivery of a 28 -year-old mother. Birth weight was $3.6 \mathrm{~kg}$. At 2 days of age she began to vomit after each meal. Multiple formula changes resulted in no improvement. At 21 days of age she was admitted to another hospital because of persistent vomiting and weight loss. The patient's failure to thrive was thought to be secondary to poor feeding, and management consisted of another change in brand of formula, after which her vomiting improved and she started to gain weight. One day before transfer to the Riley Hospital, however, her condition worsened and she developed pallor and respiratory distress. The patient is the only child of her parents but has five half-siblings. There is no family history of adrenogenital syndrome, recurrent pulmonary infections, or cystic fibrosis.

Physical examination revealed a moderately dehydrated girl in shock and with unobtainable blood pressure. Heart rate was $160 / \mathrm{min}$ with irregular rhythm, respiratory rate was $35 / \mathrm{min}$, and temperature $37^{\circ}$. Weight was $3.0 \mathrm{~kg}$. The remainder of her physical examination, including external genitalia, was normal. Initial laboratory data revealed a hemoglobin of $13.8 \mathrm{~g} / 100 \mathrm{ml}$ with normal white blood count and differential. Urinalysis was normal. Serum sodium concentration was $119 \mathrm{mEq}$, potassium $11.1 \mathrm{mEq}$, chloride $76 \mathrm{mEq}$, and carbon dioxide content 22 $\mathrm{mmol} / \mathrm{liter}$. The serum urea nitrogen was $71 \mathrm{mg}$, glucose $79 \mathrm{mg}$, calcium $9.5 \mathrm{mg}$, and phosphorus $6.1 \mathrm{mg} / 100 \mathrm{ml}$. Roentgenograms of the chest and abdomen were normal. Electrocardiogram revealed tall $\mathrm{T}$ waves and occasional ventricular premature beats. The differential diagnosis included congenital adrenal hyperplasia with salt loss, congenital Addison's disease, congenital aldosterone systhesis defect, pseudohypoaldosteronism, or some renal abnormality.

The patient was managed with intravenous fluids, hydrocortisone, and deoxycorticosterone acetate (DOCA). When her condition stabilized, her glucocorticoid function was evaluated while on DOCA and dexamethasone. The baseline values for 17-keto and 17-OH steroids and pregnanetriol were $0.65 \mathrm{mg}, 4.3 \mathrm{mg} / \mathrm{m}^{2}$, and $0.02 \mathrm{mg}$, respectively; the normal values for children of similar age on no medication are $<2 \mathrm{mg}, 3 \pm 1 \mathrm{mg} / \mathrm{m}^{2}$, and $<0.2 \mathrm{mg}$, respec- 
tively. In response to intramuscular ACTH stimulation, 17-OH steroids increased 23-fold on days 1 and 2 and 9 -fold on day 3, thus excluding the possibility of congenital Addison's disease. Renal function studies, summarized in Table 1, were normal. During the first 4 weeks of her first admission (age 4-8 weeks), despite treatment with hydrocortisone and DOCA or 9- $\alpha$-fluorocortisol and $5-8 \mathrm{mEq} / \mathrm{kg} /$ day sodium intake, her serum potassium concentration was more than $6 \mathrm{mEq} /$ liter on 10 different days and more than $8 \mathrm{mEq} /$ liter on 3 different days. On these 3 days the serum sodium concentration was also less than $130 \mathrm{mEq} /$ liter.

\section{SPECIAL STUDIES}

These studies were done during four periods between the ages of 2 months and 35 months. Each study period lasted 1-3 weeks. If sodium intake during this period was changed, at least 3 days of equilibration were permitted before any determinations were made. Sodium and potassium intake in the diet were calculated, and any sodium supplements to the diet were measured. The patient was allowed free access to water and was ambulatory after the first year of life. All blood samples for plasma aldosterone and renin activity measurements were collected in the morning, after at least $4 \mathrm{hr}$ of continuous supine position.

\section{METHODS}

Serum, urinary, sweat, and salivary sodium and potassium concentrations were measured by flame photometry with lithium as the internal standard. Sweat chloride concentration was measured by chloridometer. Sweat was collected by pilocarpine iontophoresis, and the rate of sweat production was calculated as described by Lobeck and Huebner (24). Saliva for sodium and potassium determination was collected from the sublingual region. Stool fat determination was made by standard methods. Serum

Table 1. Renal function studies (age 4-8 weeks)

$\begin{array}{ll}\text { Blood urea nitrogen (when well hydrated) } & 5-8 \mathrm{mg} / 100 \mathrm{ml} \\ \text { Serum creatinine } & 0.5 \mathrm{mg} / 100 \mathrm{ml} \\ \text { Creatinine clearance } & 35-50 \mathrm{ml} / \mathrm{min} / 1.73 \mathrm{~m}^{2} \\ \text { Excretory urogram } & \text { Normal } \\ \text { Urine pH } & 5.0-8.0 \\ \text { Urine specific gravity } & 1.006-1.018 \\ \text { 24-hr urinary amino acid excretion } & \text { Normal }\end{array}$

and urinary pancreatic amylase were measured by polyacrylamide gel electrophoresis (28). Urinary aldosterone determinations were done by the method of Kliman and Peterson (19). Plasma aldosterone was measured by radioimmunoassay during study period 2 using paper chromatography (27) and in study periods 3 and 4 using an antibody capture method (13). Plasma renin activity was measured by radioimmunoassay for angiotensin I (16). Red blood cell sodium and potassium concentrations were measured as described by Zarkowski et al. (45).

\section{RESULTS}

\section{STUDY PERIOD 1: EFFECTS OF VARYING SODIUM INTAKE (FIG. 1)}

This study was done at age $8-12$ weeks and was initiated 2 days after the patient's serum sodium and potassium had been restored to normal by increased sodium intake. Throughout this period, $2-4$ mg DOCA/day was administered intramuscularly. During the first 10 days of study she was also given hydrocortisone, $5 \mathrm{mg} /$ day.

During the first 10 days of the study the patient had $12-24 \mathrm{mEq}$ sodium intake/day (4-8 mEq/ $\mathrm{kg} /$ day $)$. Despite this intake, from day 3 onward the serum sodium was consistently less than 135 $\mathrm{mEq} /$ liter. Serum potassium was higher than $5.5 \mathrm{mEq} /$ liter throughout these 10 days. Her urinary aldosterone excretion at this time was elevated to $43 \mu \mathrm{g} / 24 \mathrm{hr}$ (normal value for children on ad libitum sodium intake is $2-26 \mu \mathrm{g} / 24 \mathrm{hr}$ ). On the 11 th day she developed diarrhea and dehydration. Her weight decreased by $4 \%$, serum sodium decreased to $121 \mathrm{mEq} /$ liter, and serum potassium increased to $8.3 \mathrm{mEq} /$ liter. The patient was given an increased amount of sodium and fluid over the next 4 days to correct dehydration and hyponatremia.

From day 16 through 24 (Fig. 1, right half) she was given a high sodium intake of 40-60 mEq/day $(12-16 \mathrm{mEq} / \mathrm{kg} / \mathrm{day})$. With this level of sodium intake she gained weight and the serum sodium and potassium were normal on most days.

\section{INTERVAL}

The patient was discharged on a daily sodium supplement of $30-40 \mathrm{mEq}$ to her diet. During the next 10 months she grew normally and her blood pressure was normal. Twenty-four-hour urinary excretion of $17-\mathrm{OH}$ and 17 -keto steroids (while on 9- $\alpha$ fluorocortisol but off glucocorticoids) was $5.7 \mathrm{mg} / \mathrm{m}^{2}$ (normal $3 \pm 1 \mathrm{mg} / \mathrm{m}^{2}$ ) and $0.3 \mathrm{mg}$ (normal, $<0.5$ ), respectively, thus excluding adrenal hyperplasia with salt loss. Because urinary aldosterone excretion was increased, mineralocorticoid adminis-

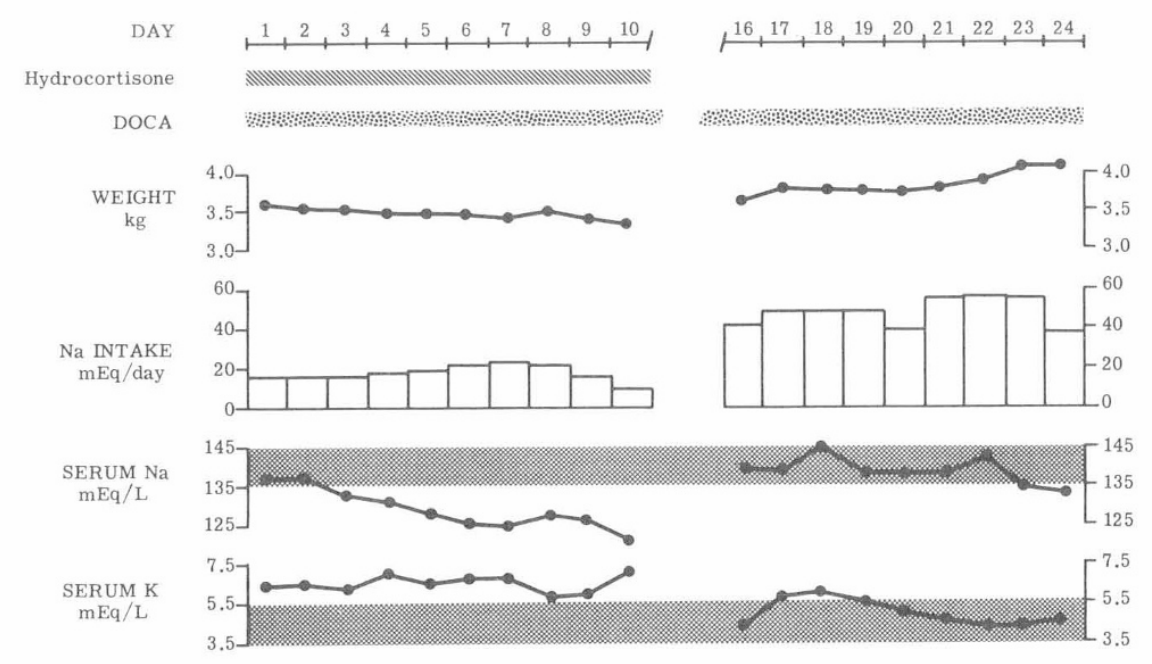

URINARY ALDO $\mu \mathrm{g} / \mathrm{day}$

43

Fig. 1. Effect of varying sodium intake on serum sodium and potassium concentration. (Note: sodium intake is depicted by total height of the bar on each day.) $A L D O$ : aldosterone. 
tration was stopped and her diagnosis was considered to be pseudohypoaldosteronism. She was hospitalized twice during this interval for dehydration, hyponatremia, hyperkalemia, and azutemia. Her mother also described that at home the patient sweated excessively.

\section{STUDY PERIOD 2: SODIUM BALANCE STUDY (FIG. 2)}

This study was done at age 12 months. From day 1 through 7 , despite a daily sodium intake of $40-50 \mathrm{mEq}(5-6 \mathrm{mEq} / \mathrm{kg} / \mathrm{day})$, normal serum sodium concentration, and no weight gain, urinary excretion of sodium was only $3-10 \mathrm{mEq} /$ day. Stool sodium at this time was less than $1 \mathrm{mEq} /$ day. A sweat chloride concentration, obtained to help account for the 35-40 mEq difference between daily sodium intake and output, was elevated to $116 \mathrm{mEq} /$ liter (normal less than 30) on day 3 and $136 \mathrm{mEq} /$ liter on day 7. The peripheral venous plasma renin activity (PRA) collected on day 3 was $16 \mathrm{ng} / \mathrm{ml} / 3 \mathrm{hr}$ (normal value for supine PRA in adults on ad libitum sodium intake in our laboratory i., $1.0-3.0 \mathrm{ng} / \mathrm{ml} / 3 \mathrm{hr}$ and during high sodium intake less than $1.5 \mathrm{ng} / \mathrm{ml} / 3 \mathrm{hr}$; although results in normal young children have not been adequately standardized in our laboratory, in three normal children between the ages of 5 months and 2 years, supine PRA while on normal diet was less than $22 \mathrm{ng} / \mathrm{ml} / 3 \mathrm{hr}$ in all. Stalker et al. (42) have recently reported that plasma renin activity in infants between the ages of 2 months and 3 years is $4.6 \pm 0.9 \mathrm{ng} / \mathrm{ml} / \mathrm{hr}$ ). Her plasma aldosterone was elevated to more than $73 \mathrm{ng} / 100 \mathrm{ml}$ (47) (in two normal infants while on normal diet results of supine plasma aldosterone in our laboratory were 17-28 ng/ $100 \mathrm{ml}$, respectively, and in two children with cystic fibrosis, aged 6 months and 4 years, results were 29 and $8 \mathrm{ng} / 100 \mathrm{ml}$, respectively. Kowarski et al. (20), using a different technique, have recently reported that mean plasma aldosterone in infants less than 1 year of age was $79.9 \pm$ $47.9 \mathrm{ng} / 100 \mathrm{ml}$ and in children $1-15$ years of age $24.9 \pm 17.6 \mathrm{ng} /$ $100 \mathrm{ml}$ ). The patient's potassium intake during this study period varied between 20 and $30 \mathrm{mEq} /$ day and urinary potassium excretion between 5 and $15 \mathrm{mEq} /$ day even though through most of this period her serum potassium was higher than $5.5 \mathrm{mEq} /$ liter. Un-

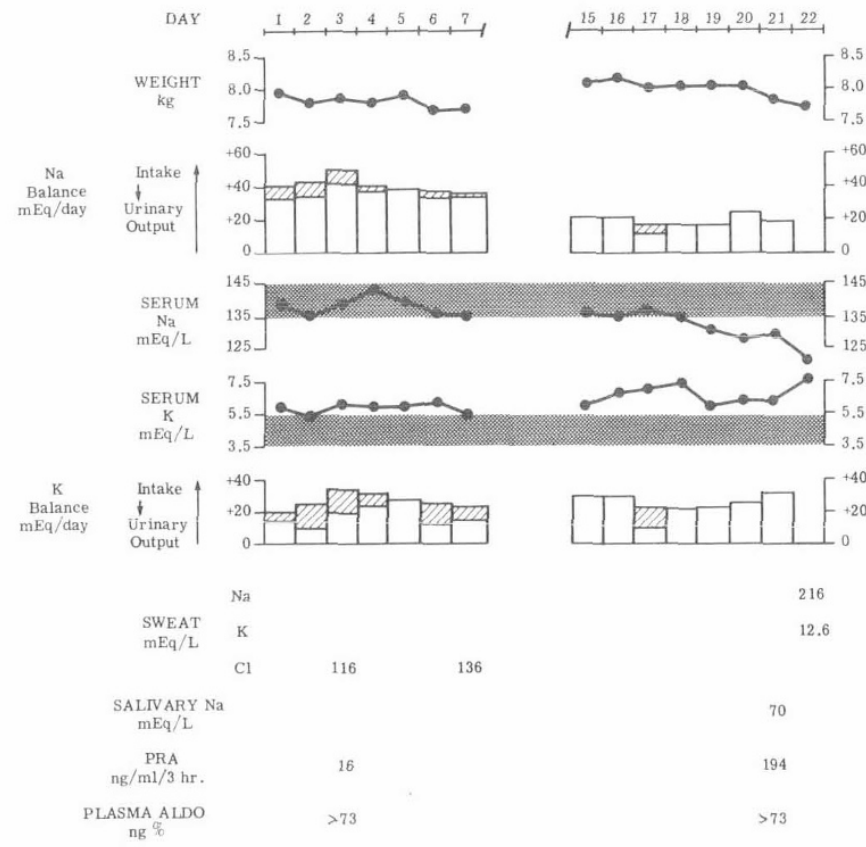

Fig. 2. Sodium balance study. (Note: in this and Figures 2-4 daily sodium and potassium intake are depicted by the total height of the bar, daily urinary output by the cross-hatched area on the bar, and difference between intake and urinary output by the clear area on the bar. On the days which show no hatched areas, adequate urinary collections could not be made and the bar represents intake only.) PRA: plasma renin activity; $A L D O$ : aldosterone. der usual circumstances when hyperkalemia is present, the urinary excretion of potassium rises and limits a further rise in serum potassium concentrations.

From day 15 through 22 (Fig. 2, right half) the patient's daily sodium intake was reduced to $18-24 \mathrm{mEq}(2-3 \mathrm{mEq} / \mathrm{kg} / \mathrm{day})$. Her weight and serum sodium concentration gradually fell and serum potassium concentration remained above normal throughout this period. On day 21 (while her serum sodium concentration and weight were decreasing) her PRA was markedly increased over the value on day 3. Plasma aldosterone on day 21 was still quite elevated. Sweat sodium on the morning of day 22 was elevated to $216 \mathrm{mEq} /$ liter (normal $16.7 \pm 8.7$ and in cystic fibrosis $106.3 \pm 24.8$ ) and potassium was $12.6 \mathrm{mEq} /$ liter (normal $11.2 \pm$ 2.2 and in cystic fibrosis $14.0 \pm 2.3)(24)$. Salivary sodium was elevated to $70 \mathrm{mEq} /$ liter (normal $16.0 \pm 10.6$ and in cystic fibrosis $27 \pm 10.7$ ) and salivary potassium was $27 \mathrm{mEq} /$ liter (normal $20 \pm$ 5.3 and in cystic fibrosis $21 \pm 6.1$ ) (10). On day 22 she developed further weight loss and her serum urea nitrogen rose to $50 \mathrm{mg} / 100$ $\mathrm{ml}$. Her condition was stabilized over the next 3 days by administration of additional sodium. One week after this she was placed on 9- $\alpha$-fluorocortisol, $0.1 \mathrm{mg}$ daily for 6 days, after which sweat sodium was repeated and found to be $184 \mathrm{mEq} /$ liter. Further evaluation for cystic fibrosis at this time, including a chest roentgenogram and 72 -hr fecal fat excretion, was normal.

\section{INTERVAL 2}

During the next 22 months the patient was maintained on 35-70 $\mathrm{mEq} /$ day sodium supplement to her diet. Her blood pressure on this regimen was normal. During this period she developed only one recognized episode of hyponatremia, hyperkalemia, and azotemia at age 19 months. At age 26 months she developed a right middle lobe pneumonia; the infiltrate, however, took 12 months to clear. Tuberculin test with intermediate strength purified bovine derivative (PPD) was negative. Her growth and development during this interval were normal.

\section{STUDY PERIOD 3: EFFECTS OF GRADUAL REDUCTION OF SODIUM INTAKE (FIG. 3)}

This study was done at age 33 months. Her sodium intake was reduced in a stepwise fashion from $100 \mathrm{mEq} / \mathrm{kg} /$ day $(8 \mathrm{mEq} / \mathrm{kg} /$ day) to $20 \mathrm{mEq} / \mathrm{kg} /$ day $(1.6 \mathrm{mEq} / \mathrm{kg} /$ day $)$. The urinary sodium excretion gradually fell so that when her daily sodium intake was $20 \mathrm{mEq}$, urinary sodium excretion was only $3 \mathrm{mEq}$. Her sweat sodium was still markedly elevated, but despite a 5 -fold reduction in sodium intake her serum sodium and potassium concentrations remained normal. However, with reduction in sodium intake, PRA, plasma aldosterone, and urinary aldosterone excretion all increased to very high values. Blood pressure was normal throughout the study period. Creatinine clearance during this admission was $139 \mathrm{ml} / \mathrm{min} / 1.73 \mathrm{~m}^{2}$. Red blood cell sodium concentration was $18 \mathrm{mEq} /$ liter cells (normal, 16-25) and potassium concentration $112 \mathrm{mEq} /$ liter cells (normal, 82-108).

Fecal fat excretion was $7 \%$ of intake. Serum and urinary pancreatic amylase (amy-2) levels were normal. Patients with cystic fibrosis have little detectable pancreatic amylase (amy-2) in their serum or urine (28). To determine whether she sweated excessively her sweat production rate was determined; it was 8 $\mathrm{g} / \mathrm{m}^{2} / \mathrm{min}$. This is in the normal range both for normal children and children with cystic fibrosis (24).

\section{INTER VAL 3}

After the above study she was discharged on a normal diet with no sodium supplement. On the above regimen she continued to do well and to gain weight and maintain normal serum electrolytes.

\section{STUDY PERIOD 4: EFFECTS OF DEXAMETHASONE (FIG. 4)}

This study was done at age 35 months while on a regular diet with sodium intake varying between 20 and $35 \mathrm{mEq} /$ day $(2-3$ 

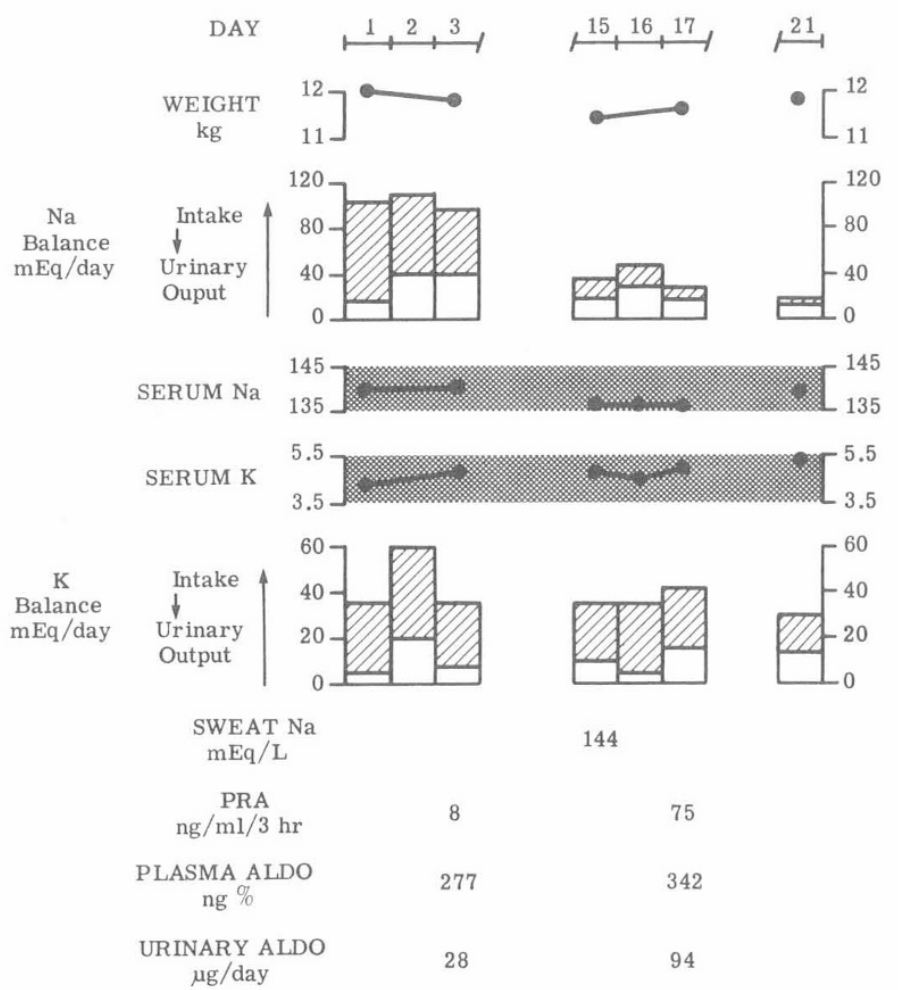

Fig. 3. Effects of gradual reduction of sodium intake. See legend to Figure 2 for explanation of symbols.

$\mathrm{mEq} / \mathrm{kg} /$ day). After baseline plasma aldosterone, PRA, and cortisol measurements, dexamethasone, $1 \mathrm{mg}$ twice daily, was given orally for 4 days. The baseline cortisol level was normal and decreased markedly after dexamethasone. The baseline plasma aldosterone level was considerably elevated. One day after dexamethasone administration plasma aldosterone level showed further elevation; by the 4 th day the level had fallen below baseline value but was still considerably above normal.

\section{SUBSEQUENT COURSE}

Since the last study, the patient has been followed for 8 months on a regular diet. Her height and weight gain has been normal. Blood pressure has been $90-100$ systolic and 60-70 diastolic. She has no evidence of pulmonary or gastrointestinal disease. She has maintained normal serum electrolytes. Sweat electrolytes were sodium $160 \mathrm{mEq} /$ liter, chloride $139 \mathrm{mEq} /$ liter, and potassium 7.7 $\mathrm{mEq} /$ liter.

\section{DISCUSSION}

Pseudohypoaldosteronism is an uncommon renal tubular disorder first described by Cheek and Perry in 1958 (5). Since then 19 additional patients have been reported $(1,7,11,17,22,32-35,37$, 44). During infancy all the reported patients had renal sodium wasting and urinary sodium concentration generally exceeded 30 $\mathrm{mEq} /$ liter even in the presence of hyponatremia unless the patients were extremely dehydrated. Aldosterone secretion or excretion rates were always high in these patients when they were on normal sodium intake. With very high sodium intakes in some reported patients these rates fell into the normal range $(11,22)$, whereas in most they continued to be extremely high $(33,34,44)$. When measured, sweat sodium or chloride concentrations have been less than $50 \mathrm{mEq} /$ liter $(5,11,34,35)$, except for one of the reported patients whose initial sweat sodium was $93 \mathrm{mEq} /$ liter; however, a repeat value was $47 \mathrm{mEq} /$ liter (35).

Sweat sodium and/or chloride concentrations are elevated in a number of conditions including cystic fibrosis, hypoaldosteronism,
Addison's disease, panhypopituitarism, nephrogenic diabetes insipidus, ectodermal dysplasia, familial hypoparathyroidism with anodontia, and hypothyroidism $(6,23)$. The present patient does not seem to have any of these conditions. Although the possibility of cystic fibrosis cannot be completely excluded in this patient, we think that this possibility is unlikely because of negative family history, very unusual clinical course characterized by repeated episodes of hyperkalemia, elevated levels of plasma aldosterone, and normal pancreatic function (normal stool fat excretion and normal urinary and serum pancreatic amylase (amy-2) levels). Most children with cystic fibrosis develop pancreatic insufficiency early in life; however, in large series up to $10 \%$ patients with cystic fibrosis are reported to have either normal or partial loss of pancreatic function $(8,40)$. Patients with cystic fibrosis are known to develop shock and hyponatremia with heat prostration (18) and occasionally dehydration and hyponatremia even in cold weather (9). However, during these episodes, their serum potassium concentration is either normal or low (9), and development of hyperkalemia has not been reported. Aldosterone secretion rate in young patients with cystic fibrosis has been previously reported to be normal (29); however, the values in teenagers with advanced disease may be elevated (41). Plasma aldosterone levels measured by us in two young children with cystic fibrosis were normal, unlike the patient of this report. Because of the reasons mentioned above, if this patient is to be considered a patient suffering from cystic fibrosis, she is a very unusual patient with the disorder. Furthermore, it must be postulated that she has two unrelated disorders, cystic fibrosis and a defect in aldosterone metabolism.

The clinical course in our patient has been very similar to patients with classic pseudohypoaldosteronism. Most of these patients, with increasing age (usually by $1-2$ years), lose their tendency for excessive sodium wasting and can be maintained on normal diets $(1,11,33,34)$. In this respect our patient resembles the other reported patients. She differs, however, from all other reported cases of pseudohypoaldosteronism in that the source of her excessive sodium loss has been from the sweat glands instead of
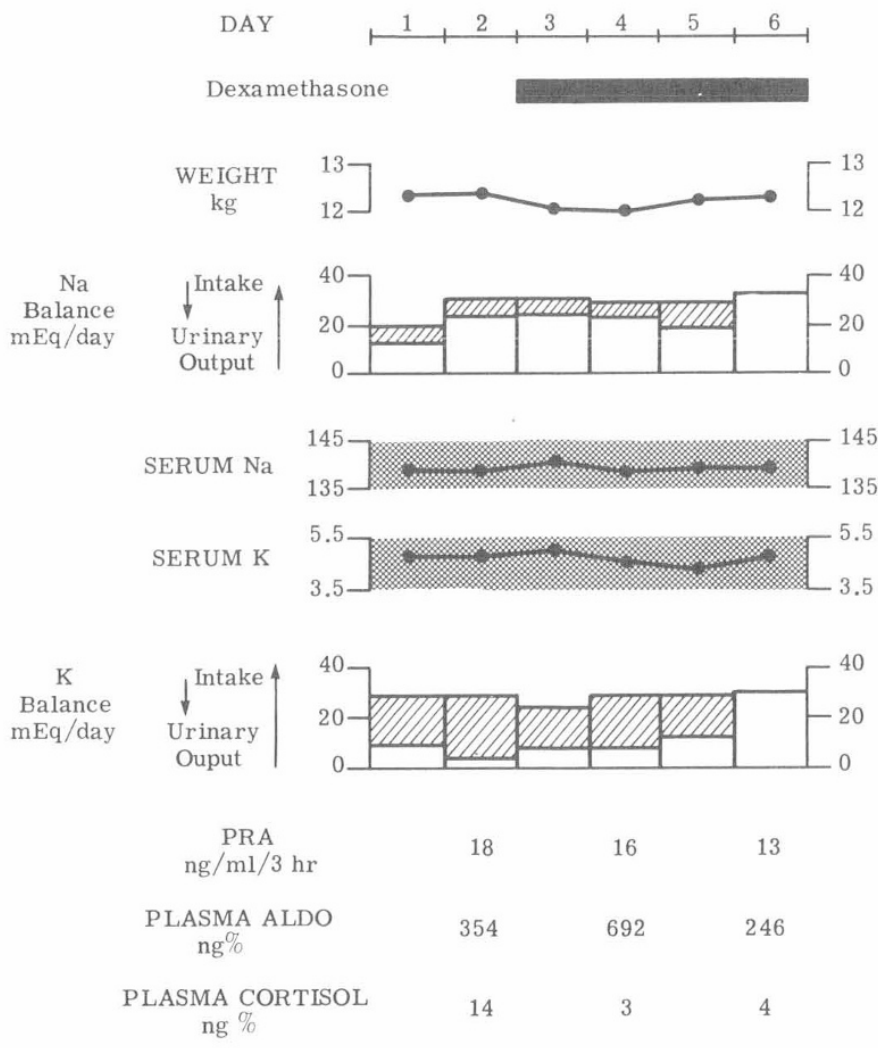

Fig. 4. Dexamethasone suppression test. See legend to Figure 2 for explanation of symbols. 
from the kidney. Parenthetically, her salivary sodium concentration is also very high, although she has no apparent fecal wasting of sodium.

In addition to its action on the distal renal tubule, aldosterone is known to affect sweat, salivary, and colonic sodium excretion (30). In normal children, after administration of intramuscular aldosterone (15) or oral 9- $\alpha$-fluorocortisol for 2 days (25), sweat sodium concentration falls by about $15-25 \%$, and sweat potassium concentration is minimally increased. In children with cystic fibrosis, $9-\alpha$-fluorocortisol is without effect in reducing the elevated sweat sodium concentrations (25). In the present patient, after 6 days of 9- $\alpha$-fluorocortisol administration, sweat sodium concentration was still elevated to $184 \mathrm{mEq} /$ liter.

The high aldosterone excretion rate at age 2 months and high PRA and plasma aldosterone levels at age 1 year in the present patient were initially attributed to the excessive sodium wasting in sweat resulting in loss of "effective" plasma and/or extracellular fluid volume similar to patients with classic pseudohypoaldosteronism. This reasoning, however, fails to explain the high plasma aldosterone values at age 33 months while on a very high sodium intake. Several investigators $(33,34)$ have reported continued high aldosterone secretion rates in older patients with pseudohypoaldosteronism who no longer manifest excessive sodium wasting. Postel-Vinay et al. (33) have found a partial renal tubular response to mineralocorticoids in a 9-year-old boy with pseudohypoaldosteronism who no longer had obvious renal tubular sodium wasting but had continued to have an increased aldosterone secretion rate. As an infant this patient was reported to lose excessive amounts of sodium in the urine (38). The observation led these authors to postulate that the sodium wasting defect in pseudohypoaldosteronism may be a proximal tubular defect. This explanation would fail to explain the associated hyperkalemia present in these patients because reciprocal exchange of sodium and potassium is conceded to be a distal tubular phenomenon. In Bartter's syndrome, which several authors consider to be due to a defect in proximal tubular sodium reabsorption (14), there is an associated hypokalemia rather than hyperkalemia because the distal tubular sodium-potassium exchange is intact and can respond to the elevated aldosterone levels. At present there is no completely satisfactory explanation for the persistence of hyperaldosteronism in older patients with pseudohypoaldosteronism who no longer have the sodium wasting defect.

The other known stimuli for aldosterone secretion are high serum potassium, ACTH, and perhaps low serum sodium concentration as a direct effect (21). High serum potassium may have contributed to high plasma aldosterone during the first 19 months of our patient's life but fails to explain the persistence of high plasma aldosterone values at age 33 months. Boyd et al. (3) have recently shown that intracellular rather than extracellular potassium concentration is an important stimulus for aldosterone production. We do not know whether in our patient the intracellu-

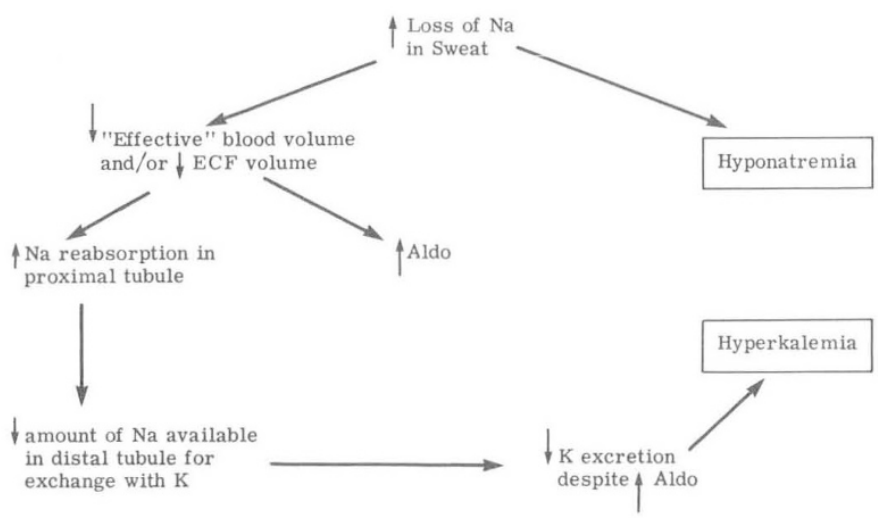

Fig. 5. Possible mechanism of hyperkalemia and hyponatremia in this patient. ECF: extracellular fluid; Aldo: aldosterone. lar potassium concentration has been elevated and has acted as a stimulus for increased aldosterone production. Her red blood cell potassium concentration is slightly elevated but we have as yet not measured potassium concentration in other cellular tissues. ACTH is unlikely to be contributing to increased plasma aldosterone in this patient because dexamethasone failed to suppress the high plasma aldosterone values to normal, unlike patients with dexamethasone-suppressible hyperaldosteronism $(31,43)$. One possible explanation may lie in persistence of the basic defect of the sweat gland in our patient, and of the renal tubule in patients with classical pseudohypoaldosteronism. These defects may stimulate aldosterone production by yet unexplained mechanisms, even though the sodium wasting defect in older patients is not apparent on a normal diet. Alternatively, because of sodium wasting defect in early life, these patients develop a state of "tertiary hyperaldosteronism," functionally not dissimilar to tertiary hyperparathyroidism observed in patients with chronic renal failure. This "tertiary hyperaldosteronism" may take several years to regress to normal after improvement in the sodium wasting defect.

Patients with classic pseudohypoaldosteronism develop hyperkalemia during infancy and beyond when their sodium intake is not considerably above average. This is thought to be due to their limited ability to excrete potassium in exchange for sodium in the distal tubule because of an end organ resistance to the action of aldosterone in the distal tubule. Only when very large quantities of sodium are available in the distal tubule can sufficient potassium be excreted to prevent hyperkalemia. This explanation, however, fails to explain hyperkalemia in our patient because she had normal renal function without any evidence of urinary sodium wasting.

One of the explanations for hyperkalemia in the present patient has been summarized schematically in Figure 5. The scheme of events is as follows. Excessive loss of sodium in sweat resulted in a reduced "effective" plasma and/or extracellular fluid volume and hyponatremia. This reduction in "effective" volume resulted in increased sodium reabsorption by the proximal tubule and also an increase in plasma aldosterone level by the stimulation of plasma renin activity. Increased sodium reabsorption in proximal tubule resulted in a reduced amount of sodium available in distal tubule for exchange with potassium, thereby reducing potassium excretion, despite an increased aldosterone level, thus resulting in hyperkalemia. This scheme is based on the following known principles of renal physiology: $(l)$ whenever "effective" plasma and/or extracellular fluid volume are reduced, increased amounts of sodium are reabsorbed in the proximal and the distal tubule $(2,12) ;(2)$ potassium excretion in the distal and collecting tubules is dependent on sodium delivery to these segments $(4,26)$; and (3) when delivery of sodium to the distal and collecting tubule is reduced, less potassium is excreted even though excessive amounts of mineralocorticoids may be present $(4,36,39)$.

\section{SUMMARY .}

This report describes a patient who represents a variant of pseudohypoaldosteronism with excessive loss of sodium from the sweat and salivary glands instead of the renal tubule. We are postulating that hyperkalemia in this patient developed secondary to excessive sodium loss in the sweat. This resulted in increased sodium reabsorption in the proximal renal tubule, with consequent reduced delivery of sodium to the distal tubule for exchange with potassium, thereby limiting the excretion of potassium.

\section{REFERENCES AND NOTES}

1. Alvarez, M. N., Barnes, N. D., and Stickler, G. B.: Salt wasting nephropathy or pseudohypoaldosteronism in twins. Pediat. Res., 8: 453 (1974).

2. Berliner, R. W.: Outline of renal physiology. In: M. B. Strauss and L. G. Welt: Diseases of the Kidney, Chap. 2 (Little Brown and Company, Boston, 1971).

3. Boyd, J., Mulrow, P. J., Palmore, P., and Silvo, P.: Importance of potassium in the regulation of aldosterone production. Circ. Res., 32 (suppl. 1): 39 (1973). 
4. Brenner, B.M., and Berliner, R. W.: The transport of potassium. In: J Orloff and R. W. Berliner: Handbook of Physiology (Section 8: Renal Physiology), Chap. 16 (American Physiological Society Publication, Washington, D.C., 1973).

5. Cheek, D. B., and Perry, J. W.: A salt wasting syndrome in infancy. Arch. Dis. Childhood, 33: 252 (1958)

6. Conn, J. W.: Electrolyte composition of sweat. Arch. Int. Med., 83: 416 (1949)

7. Corbeel, L.: Diabete salin du nourrisson sans insuffisance surrenalienne. Pediatrie, 18: 557 (1963).

8. di Sant'Agnese, P. A.: Fibrocystic disease of the pancreas with normal or partial pancreatic function. Pediatrics, 15: 683 (1955).

9. di Sant'Agnese, P. A.: Salt depletion in cold weather in infants with cystic fibrosis of the pancreas. J. Amer. Med. Ass., 172: 2014 (1960).

10. di Sant'Agnese, P. A., Grossman, H., Darling, R. C., and Denning, C. R.: Saliva, tears and duodenal contents in cystic fibrosis of the pancreas. Pediatrics, 22: 507 (1958).

11. Donnell, G. N., Litman, N., and Roldan, M.: Pseudohypo-adrenalocorticism. Amer. J. Dis. Child., 97: 813 (1959).

12. Early, L. E., and Daugharty, T. M.: Sodium metabolism. N. Engl. J. Med., 281: $72(1969)$.

13. Gomez-Sanchez, C., Kem, D. C., and Kaplan, D.M.; A radioimmunoassay for plasma aldosterone by immunologic purification. J. Clin. Endocrinol. Metab., 36: 795 (1973)

14. Goodman, A. D., Vagnucci, A. H., and Hartfort, P. M.: Pathogenesis of Bartter's syndrome. N. Engl. J. Med., 281: 1435 (1969).

15. Grand, R. J., di Sant'Agnese, P. A., Talamo, R. C., Pallavicini, J. C., and Rich, K.: The effects of exogenous aldosterone on sweat electrolytes. J. Pediat., 70: 346 (1967).

16. Haber, E., Koerner, T., Page, L. B., Kliman, B., and Purnode, A.: Application of a radio immunoassay for angiotensin I to the physiologic measurements of plasma renin activity in normal human subjects. J. Clin. Endocrinol. Metab., 29: 1349 (1969)

17. Jeune, M., Lamit, J., Loras, B., Do, F., and Forest, M.: Pseudohypoaldosteronisme. Arch. Franç. Pediat., 24: 714 (1967).

18. Kessler, W. R., and Andersen, D. H.: Heat prostration in fibrocystic disease of pancreas and other conditions. Pediatrics, 8: 648 (1951).

19. Kliman, B., and Peterson, R. E.: Double isotope derivative assay of aldosterone in biological extracts. J. Biol. Chem., 235: 1639 (1960).

20. Kowarski, A., Katz, H., and Migeon, C. J.: Plasma aldosterone concentration in normal subjects from infancy to adulthood. J. Clin. Endocrinol. Metab., 38: 489 (1974).

21. Laragh, J. H., and Sealy, J. E.: The renin-angiotensin-aldosterone hormonal system and regulation of sodium, potassium and blood pressure homeostasis. In: J. Orloff and R. W. Berliner: Handbook of Physiology (Section 8: Renal Physiology), Chap. 26 (American Physiological Society Publication, Washington, D.C., 1973)

22. Lelong, M., Alagille, D., Phillippe, C., Gentil, C., and Gabilan, J. C.: Diabete salin par insensibilite congenitale du tubule a l'Aldosterone: "Pseudohypoadrenocorticisme." Rev. Franç. Etud. Clin. Biol., 5: 558 (1960).

23. Lobeck, C. C.: Cystic fibrosis. In: J. B. Stanbury, J. B. Wyngaarden, and D. S. Fredrickson: The Metabolic Basis of Inherited Disease, p. 1613 (McGraw-Hill Book Co., New York, 1972).

24. Lobeck, C. C., and Huebner, D.: Effect of age, sex and cystic fibrosis on the sodium and potassium content of sweat. Pediatrics, 30: 172 (1962).

25. Lobeck, C. C., and McSherry, N. R.: Response of sweat electrolyte concentrations to 9 alpha-fluorohydrocortisone in patients with cystic fibrosis and their families. J. Pediat., 62: 393 (1963).

26. Malinic, G., Klose, R. M., and Giebisch, G.: Micropuncture study of distal tubular potassium and sodium transport in rat nephron. Amer. J. Physiol., 211: 529 (1966)

27. Mayes, D., Furuyama, S., Kem, D. C., and Nugent, C. A.: A radio-immunoassay for plasma aldosterone J. Clin. Endocrinol Metab., 30:682 (1970)

28. Merritt, A. D., Rivas, M. L., Bixler, D., and Newell, R.: Salivary and pancreatic amylase: Electrophoretic characterizations and genetic studies. Amer. J. Human Genet., 25: 510 (1973)

29. Montalvo, J. M., McCaa, C. S., and Cole, W. D.: Aldosterone metabolism in children with cystic fibrosis and their parents. J. Clin. Endocrinol. Metab., 28. $582(1968)$

30. Murlow, P. J., and Forman, B. H.: The tissue effects of mineralocorticoids Amer. J. Med., 53: 561 (1972).

31. New, M. I., Siegal, E. J., and Peterson, R. E.: Dexamethasone suppressible hyperaldosteronism. J. Clin. Endocrinol. Metab., 37: 93 (1973).

32. Polonovski, C., Zittoun, R., and Mary, F.: Hypocorticisme global hypoaldosteronisme et pseudo-hypoaldosteronisme due nourrisson. Arch. Franc. Pediat., 22: 1061 (1965)

33. Postel-Vinay, M. C., Alberti, G. M., Ricour, C., Limal, J., Rappaport, R., and Royer, P.: Pseudohypoaldosteronism: Persistence of hyperaldosteronism and evidence for renal tubular responsiveness to endogenous aldosterone. J. Clin. Endocrinol. Metab., 39: 1038 (1974).

34. Proesmans, W., Geussens, H., Corbeel, L., and Eeckels, R.: Pseudohypoaldosteronism. Amer. J. Dis. Child., 126: 510 (1973)

35. Raine, D. N., and Roy, J.: A salt-losing syndrome in infancy: Pseudophypoadrenocorticalism. Arch. Dis. Childhood, 37: 548 (1962).

36. Relman, A. S., and Schwartz, W. B.: Effect of DOCA on electrolyte balance in normal man and its relation sodium chloride intake. Yale J. Biol. Med., 24: 540 (1952).

37. Rosler, A., Thedor, R., Gazit, E., Biochis, H., and Rabinowitz, D.: Salt wastage, raised plasma renin activity, and normal or high plasma aldosterone: A form of pseudohypoaldosteronism. Lancet, $i: 959$ (1973).

38. Royer, P., Bonnette, J., Mathieu, H., Gabilan, J., Klutchko, G., and Zittoun, R.: Pseudo-hypoaldosteronism. Ann. Pediat., 39: 596 (1963).

39. Seldin, D. W., Welt, L. G., and Cort, J.: The role of sodium salts and adrenal salts in the production of hypokalemic alkalosis. Yale J. Biol. Med., 29: 229 (1956).

40. Shwachman, H., Leubner, H., and Catzel, P.: Mucoviscidosis. Advan. Pediat., 5:249 (1955).

41. Simpoulos, A. D., Lapey, A., Boat, T. F., di Sant'Agnese, P. A., and Bartter, F. C.: The renin-angiotensin-aldosterone system in patients with cystic fibrosis of the pancreas. Pediat. Res., 5: 626 (1971).

42. Stalker, P., Kotchen, T., Kotchen, J. M., and Holland, N. H.: Peripheral plasma renin activity in normal children. Pediat. Res., 9: 379 (1975).

43. Sutherland, D. J., Ruse, J. L., and Laidlaw, J. C.: Hypertension, increased aldosterone secretion and low plasma renin activity relieved by dexamethasone. Canad. Med. Ass. J., 95: 1109 (1966).

44. Trung, P. H., Piussan, C., Rodary, C., Legrand, S., Attal, C., and Mozziconacci, P.: Etude de taux de decretion de l'aldosterone et de l'ativite de la renine plasmatique d'un cas de pseudophypoaldosteronisme. Arch. Franç. Pediat., 27: 603 (1970).

45. Zarkowski, H. S., Oski, F. A., Shaafi, R., Shohet, S. B., and Nathan, D. G. Congenital hemolytic anemia with high sodium, low potassium red cells. N. Engl. J. Med., 278: 573 (1968)

46. We are very grateful to the following faculty members of Indiana University School of Medicine: Dr. Ira K. Brandt, Professor of Pediatrics, for constructive criticism and useful suggestions in preparation of this manuscript; Dr. Carl W. Trygstad, formerly Associate Professor of Pediatrics (now Associate Professor of Pediatrics, UCLA School of Medicine, Harbor General Hospital, California), for help in initial studies performed on the patient; Dr. Donald A. Merritt, Professor of Genetics, for urinary and serum pancreatic amylase determinations; and Dr. Melvin Glick, Special Chemistry, for various sweat determinations. We would like to give our thanks to Mrs. Patti Sutko for her excellent secretarial help in preparation of this manuscript.

47. A plasma aldosterone level of $73 \mathrm{ng} / 100 \mathrm{ml}$ was the highest value which could be accurately measured without further dilutions of the sample.

48. This paper was presented in part at the Society for Pediatric Research Meeting, Washington, D.C., May 1974.

49. This research was supported in part by Public Health Service Grant HL14159 (Specialized Center of Research in Hypertension).

50. Requests for reprints should be addressed to: S. K. Anand, M.B.B.S., Renal Division, Children's Hospital of Los Angeles, 4650 Sunset Blvd., Los Angeles, Calif. 90027 (USA).

51. Accepted for publication February 17, 1976. 